\title{
INTEGRASI REMEDIASI KESULITAN BELAJAR MENGGUNAKAN MODEL CORE BERBANTUAN BOOKLET TENTANG GETARAN GELOMBANG DI SMP
}

\author{
${ }^{1 *}$ Ariza Fitriani safira ${ }^{2}$ Haratua Tiur Maria Silitonga, ${ }^{3}$ Syukran Mursyid \\ 1,2,3 Universitas Tanjungpura, Kota Pontianak, Indonesia
}

^Email Korespondensi: arizasafira@gmail.com

\section{INFO ARTIKEL}

Diterima 00 Juni 2020

Dipublikasikan 00 Agustus 2020

\begin{abstract}
This research aims to examine the effectiveness of the integrated remediation using bookletassisted CORE leraning model to reduce students' learning difficulties about vibrations and waves at SMP Negeri 2 Pontianak. The research design is One-Group Pretest-Posttest Design with 27 students in class VIII C as samples using the intact group technique. The instruments are two-tiered multiple choice tests to analyze students' learning difficulties related to concepts and essay tests to analyze students' learning difficulties related to errors in solving problems. Based on the results, it is found that: (1) Students' total misconceptions decreasing by $84.2 \%$. (2) There is a significant conceptual change in all test items. (3) All students' total errors in solving questions decreased by $78.32 \%$ (4) There are significant difference between the number of students' initial and final mistakes. (5) The percentage of all students' learning difficulties decreased by $78.91 \%$. (6) The remediation integration using CORE model assisted by a booklet has a high effectiveness to reduce students' learning difficulties. The result of this study is expected to be a consideration for teachers in designing learning difficulties' remediation activities for students, especially about vibrations and waves.
\end{abstract}

Kata Kunci: CORE Learning Model, Booklet, Students' Learning Difficulties, Vibration and Waves

\section{Pendahuluan}

Salah satu pelajaran yang dianggap paling sulit adalah Fisika. Menurut penelitian yang dilakukan Eikici (2016), kebanyakan siswa merasa bahwa, walaupun pada dasarnya fisika adalah ilmu yang mempelajari kejadian alam, namun cakupan materi dan konsep yang harus dikuasai dalam pelajaran fisika di sekolah terlalu banyak jika dibandingkan dengan yang diperlukan dalam kehidupan nyata. Ini kemudian menimbulkan pola pikir pada siswa bahwa fisika sulit dan membosankan, apalagi jika lingkungan sekelilingnya juga menganggap demikian dan guru tidak berusaha menanamkan pola pikir baru bahwa fisika menarik dan mudah untuk dipelajari. Menurut Akdeniz dalam Eikici (2016), dalam pelajaran IPA tingkat SMP, 70\% dari siswa kelas 8 mengalami kesulitan dalam memahami materi fisika dasar

Berdasarkan hasil wawancara yang dilakukan saat pra-riset, kebanyakan siswa mengeluh bingung mengerjakan soal-soal fisika. Saat mengerjakan soal-soal konsep, siswa merasa kesulitan dalam mengidentifikasi hubungan antara konsep satu dan yang lainnya. Hal ini disebabkan kurangnya pemahaman dalam beberapa konsep yang dianggap rumit sehingga ketika salah satu konsep tidak dapat dipahami, siswa akan kesulitan dalam menemukan hubungan dengan konsep lain yang terkait. Selain itu, siswa mengaku kesulitan dalam mengerjakan soal hitung dalam materi fisika karena tidak dapat memahami arti simbol dalam rumus dengan benar, dan bingung dalam menggunakan satuan yang tepat. Saat mengoperasikan rumus dalam soal, siswa juga mengaku kesulitan untuk mengkonversi satuan, dan merubah rumus sesuai variabel yang ditanyakan. Kesulitan-kesulitan siswa ini sesuai dengan hasil wawancara dengan guru pengampu mata pelajaran terkait, bahwa saat pembelajaran siswa memang mengalami kesulitan-kesulitan tersebut.

Beberapa kesulitan belajar yang dikemukakan siswa sesuai dengan pernyataan Wenno (2016) bahwa dalam fisika, ada empat kesulitan belajar yang dapat dialami siswa, yaitu: (1) Kesulitan menguasai konsep. (2) Kesulitan mengaitkan hubungan antar konsep. (3) Kesulitan menguasai rumus. (4) Kesulitan mengoperasikan rumus dalam 
menyelesaikan soal. Yang mana kesulitan memahami simbol dan satuan yang digunakan termasuk dalam beberapa ciri-ciri siswa kesulitan dalam menguasai rumus. Sedangkan kesulitan mengkonversi satuan dan merubah rumus sesuai variabel ditanya merupakan beberapa indikator bahwa siswa mengalami kesulitan dalam mengoperasikan rumus. Oleh karena itu, dapat dilihat bahwa, dari empat kriteria yang dikemukakan oleh Wenno tersebut, seluruhnya telah dialami oleh siswa.

Remediasi menurut Kamus Besar Bahasa Indonesia (KBBI) merupakan tindakan atau proses penyembuhan. Sedangkan menurut Sutrisno (2007) remediasi merupakan suatu proses untuk membantu kesulitan belajar yang dialami. Oleh karena itu kegiatan remediasi dilakukan untuk memperbaiki ketidakpahaman siswa selama kegiatan pembelajaran dalam materi tertentu. Namun, berdasarkan observasi lapangan yang dilakukan selama empat bulan kegiatan PPL dan hasil wawancara dengan guru pengampu, terbatasnya waktu pembelajaran menyebabkan beberapa kegiatan remedial hanya berupa pemberian tes ulang untuk memperbaiki nilai siswa, tanpa diberikan pembelajaran ulang untuk mengatasi ketidakpahaman siswa atas materi terkait. Oleh karena itu, dalam penelitian ini, peneliti menggunakan integrasi remediasi. Menurut Silitonga, dkk (2019) "to remediate misconceptions during the learning process commonly known as remediation integration." yang berarti kegiatan remediasi dilakukan saat proses pembelajaran, bukan dengan melakukan pembelajaran ulang setelah pembelajaran selesai dinamakan integrasi remediasi. Ini dilakukan dengan harapan kesulitan belajar siswa dapat diatasi selama pembelajaran berlangsung, sehingga pembelajaran dapat berlangsung lebih efisien. Berdasarkan hasil penelitian yang telah dilakukan Silitonga, dkk (2019) kegiatan integrasi remediasi dapat mengubah miskonsepsi siswa secara signifikan, memiliki efektifitas tinggi dalam meremediasi miskonsepsi siswa, serta dapat meningkatkan hasil belajar siswa.

Dalam konteks kesulitan belajar fisika, Dewi (2016) mengemukakan bahwa, secara garis besar kesulitan belajar dalam fisika dapat dibagi menjadi dua, yaitu kesulitan dalam perhitungan matematis dan pemahaman konsep. Salah satu model pembelajaran yang dapat digunakan untuk membantu kemampuan matematis siswa adalah model pembelajaran CORE. CORE merupakan akronim dari Connecting, Organizing, Reflecting, dan Extending. Menurut Jacob (Yuniarti, 2013) model CORE adalah salah satu model pembelajaran yang berlandaskan konstruktivisme. Dengan kata lain model CORE merupakan model pembelajaran yang dapat digunakan untuk mengaktifkan peserta didik dalam membangun pengetahuannya. Pada tahap connecting, siswa akan menghubungkan atau menghubungkan konsep atau pengetahuan lama yang sudah mereka miliki sebelum memasuki kelas dengan konsep baru yang dipelajari pada hari itu. Kemudian, pada tahap organizing guru akan membantu siswa untuk mengorganisir atau mengatur hasil penggabungan konsep lama dan baru yang didapat pada fase sebelumnya secara berdiskusi. Pada tahap ini guru dapat menggunakan grafik yang berbentuk jaring, tabel ataupun garis. Kemudian pada tahap reflecting, guru akan membimbing siswa mengidentifikasi kesalahan yang mereka buat dan memperbaiki miskonsepsi yang dialami siswa. Terakhir pada tahap extending, siswa secara individu menyelesaikan tugas dari guru, sekaligus menjadi kesempatan mereka untuk mengembangkan pemikiran mereka (Calfee: 2004).

Berdasarkan hasil penelitian Satriani (2015) model pembelajaran CORE dapat secara efektif meningkatkan kemampuan pemecahan matematis siswa. Sehingga diharapkan penggunaan model pembelajaran CORE dapat mengatasi kesulitan matematis siswa yakni pada penguasaan dan pengoperasian rumus dalam soal. Menurut Shoimin (2017), kelebihan model pembelajaran CORE yaitu dapat membantu mengembangkan dan melatih daya ingat siswa mengenai suatu konsep dalam materi pembelajaran sehingga juga dapat digunakan untuk membantu dalam penguasaan konsep siswa.

Dalam menggunakan model CORE diperlukan persiapan yang matang, sehingga guru dianjurkan untuk dapat mempersiapkan instrumen dan sumber belajar yang relevan dengan baik. Oleh karena itu, dalam penelitian ini digunakan satu komponen lagi yang dapat membantu model CORE, tidak hanya dalam membantu mengefektifkan proses pembelajaran, namun juga dapat membantu siswa agar dapat memperoleh penguasaan konsep yang lebih baik. Berdasarkan pemikiran itulah, dipilih booklet untuk membantu pelaksanaan proses pembelajaran. Menurut hasil penelitian Nurussianah (2015) booklet efektif untuk meremdiasi kesalahan siswa SMP, serta menurut Christporus 
(2010) booklet efektif untuk meremediasi miskonsepsi siswa pada materi getaran pada siswa SMP. Oleh karena itu penelitian ini dilakukan dengan maksud untuk mengidentifikasi efektifitas Integrasi Remediasi menggunakan model pembelajaran CORE berbantuan Booklet untuk mereduksi kesulitan belajar siswa pada materi getaran dan gelombang di SMP.

\section{Metode Penelitian}

Dalam penelitian eksperimen terdapat beberapa desain penelitian yang dapat digunakan, dan desain yang digunakan dalam penelitian ini adalah desain kelompok tunggal dengan pretes dan postes (One group pre-test posttest design). Desain ini digunakan untuk mengetahui tingkat kesulitan belajar siswa, tidak hanya setelah diberikan perlakuan, tapi juga sebelum diberikan perlakuan. Bagan bentuk penelitiannya sebagaimana yang tercantum dalam Tabel 1 sebagai berikut:

\begin{tabular}{c} 
Tabel 1 One Group Pretest-Posttest design \\
$\qquad \mathrm{O}_{1} \quad \mathrm{X} \quad \mathrm{O}_{2}$ \\
\hline
\end{tabular}

Keterangan:

$\mathrm{O}_{1} \quad=$ tes awal (pre-test)

$\mathrm{X} \quad=$ perlakuan integrasi remediasi kesulitan belajar dengan model CORE berbantuan booklet

$\mathrm{O}_{2} \quad=$ tes akhir (post-test).

(Asrori dan Ali, 2010)

Populasi dalam penelitian ini yakni seluruh siswa kelas VIII SMPN 2 Pontianak Tahun ajaran 2018/2019 yang terdiri atas 8 kelas, mulai dari kelas VIII A hingga VIII H dengan total sebanyak 251 siswa. Pengambilan sampel dilakukan dengan teknik intact group (kelompok utuh). Pemilihan kelas sampel didasarkan atas rekomendasi guru pengampu yang belum pernah mendapat materi mengenai getaran dan gelombang, hingga didapat sampel kelas VIII C dengan jumlah total sebanyak 27 siswa. Walaupun sebenarnya kelas VIII C memiliki siswa dengan jumlah total sebanyak 32 siswa, namun dikarenakan ada beberapa siswa yang tidak masuk dalam salah satu tahap penelitian seperti pretest, posttest ataupun kegiatan integrasi remediasi, maka siswa tersebut tidak termasuk dalam sampel.

Dalam penelitian ini digunakan tes diagnostik berbentuk pilihan ganda dan esai, yang dikembangkan oleh peneliti setelah melalui proses validasi. Tes diberikan sebelum perlakuan (pre-test) dan setelah perlakuan (post-test) untuk mengetahui perbedaan kesulitan belajar siswa. Sebelum digunakan instumen terlebih dahulu diuji validitas dan reliabilitasnya. Berdasarkan hasil uji validitas yang telah dilakukan, didapatkan hasil bahwa rata-rata validitas RPP memiliki nilai 4.2 (Tinggi), validitas LKS bernilai 4 (Tinggi), soal esai memiliki validitas 4.27 (Tinggi), dan pilihan ganda memiliki nilai validitas 4 (Tinggi). Menurut hasil perhitungan uji reliabiliatas, didapatkan hasil bahwa reliabilitas soal pilihan ganda pretest memiliki 0.79 (reliabel) dan pilihan ganda posttest 0.76 (reliabel), serta hasil reliabilitas soal esai pretest memiliki nilai 0.996 (sangat kuat), dan reliabilitas soal posttest bernilai 0.997 (sangat kuat).

Secara garis besar, ada tiga tahap prosedur dalam penelitian ini, yaitu tahap persiapan, tahap pelaksanaan, tahap akhir:

Tahap Persiapan

Langkah-langkah yang dilakukan pada tahap persiapan antara lain (1) Melakukan studi literatur dan studi lapangan (2) Merumuskan masalah (3) Menyiapkan instrumen penelitian berupa kisi-kisi soal, soal pretest dan posttest (4) Melakukan validasi instrument penelitian (6) Melakukan uji coba soal (7) Menganalisis hasil uji coba soal (8) Menentukan waktu penelitian 


\section{Tahap Pelaksanaan}

Langkah-langkah yang dilakukan saat tahap pelaksanaan antara lain: (1) Memberikan pretest dan posttest; (2) Mengoreksi jawaban peserta didik; (3) Memberikan perlakuan berua integrase remediasi menggunakan model CORE berbantuan booklet (4) Memberikan posttest; (5) Menganalisis data hasil posttest

\section{Tahap Akhir}

Langkah-langkah yang dilakukan ada tahap akhir antara lain: (1) Menganalisis seluruh data hasil pretest dan posttest sesuai rumusan masalah penelitian; (2) Membuat kesimpulan; (3) Menyusun laporan penelitian.

\section{Hasil dan Pembahasan}

\subsection{Hasil}

Penelitian ini dilaksanakan di SMP Negeri 2 Pontianak pada Mei 2019. Penelitian dilakukan pada siswa kelas VIII C dengan jumlah sample sebanyak 27 siswa dari total 32 siswa pada kelas tersebut. Hal ini dikarenakan terdapat beberapa siswa yang tidak mengikuti salah satu atau beberapa rangkaian kegiatan dalam penelitian ini (pretest, posttest, ataupun kegiatan integrase remediasi). Penelitian ini dilakukan untuk mengidentifikasi efektifitas integrasi remediasi kesulitan belajar siswa tentang getaran dan gelombang di SMPN 2 Pontianak.

Penelitian dilakukan selama dua minggu dengan total 4 kali pertemuan, yang mana dua kali pertemuan digunakan untuk kegiatan pretest dan posttest. Pretest dan posttest dilakukan dengan pemberian dua jenis tes berupa pilihan ganda two-tier test, dan tes esai. Tes pilihan ganda digunakan untuk mengungkap kesulitan belajar siswa mengenai konsep dan tes esai digunakan untuk mengungkap kesulitan belajar siswa mengenai pemecahan soal.

Pada soal pilihan ganda two-tier test ada dua faktor yang dianalisis, yakni profil miskonsepsi siswa dan perubahan konseptual siswa yang dinalasis dengan menggunakan uji statistic McNemar. Pada analisis miskonsepsi didapat profil miskonsepsi paling dominan pada setiap nomornya sebagaimana yang tertera pada tabel 2 berikut:

Tabel 2. Profil Miskonsepsi

\begin{tabular}{|c|c|c|c|c|}
\hline $\begin{array}{l}\text { No } \\
\text { Soal }\end{array}$ & Bentuk Miskonsepsi Dominan & $\%$ & So\% & $S_{t} \%$ \\
\hline 1 & $\begin{array}{l}\text { Perpindahan bandul dari titik maksimum menuju posisi } \\
\text { setimbang bernilai setengah getaran }\end{array}$ & 29.63 & 74.07 & 11.11 \\
\hline 2 & $\begin{array}{l}\text { Karena simpangan memiliki jarak paling kecil dan amplitudo } \\
\text { memiliki jarak lebih besar. }\end{array}$ & 22.22 & 85.19 & 14.81 \\
\hline 3 & $\begin{array}{l}\text { Bandul dengan massa lebih kecil akan mempunyai } \\
\text { kecepatan/frekuensi getar lebih besar. }\end{array}$ & 29.63 & 74.07 & 7.41 \\
\hline 4 & Semakin panjang tali, semakin besar pula frekuensi & 44.44 & 66.67 & 7.41 \\
\hline 5 & $\begin{array}{l}\text { Ketika bandul berada di titik paling jauh/ tinggi/ besar } \\
\text { kecepatannya juga maksimum }\end{array}$ & 48.15 & 70.37 & 11.11 \\
\hline 6 & $\begin{array}{l}\text { Karena bandul berada di titik setimbang maka tidak bergerak } \\
\text { sehingga kecepatannya nol }\end{array}$ & 55.56 & 66.67 & 7.41 \\
\hline 7 & $\begin{array}{l}\text { Karena pada gelombang energinya merambat, sehingga } \\
\text { partikel juga merambat }\end{array}$ & 37.04 & 62.96 & 7.41 \\
\hline 8 & Karena gelombang bunyi termasuk gelombang transversal & 29.62 & 62.96 & 7.41 \\
\hline
\end{tabular}




\begin{tabular}{lllll}
\hline $\begin{array}{l}\text { No } \\
\text { Soal }\end{array}$ & Bentuk Miskonsepsi Dominan & $\%$ & So\% & S $\%$ \\
\hline 9 & $\begin{array}{l}\text { Karena amplitudonya lebih besar, maka kecepatannya juga } \\
\text { besar }\end{array}$ & 40.74 & 77.78 & 18.52 \\
\hline 10 & $\begin{array}{l}\text { Karena kalau frekuensi mengecil, panjang gelombang juga } \\
\text { akan mengecil }\end{array}$ & & & \\
\hline 11 & Gelombang dihasilkan getaran partikel berpindah & 51.85 & 11.11 \\
\hline 12 & Pada peristiwa gelombang partikelnya berpindah & 11.11 & 77.78 & 0 \\
\hline
\end{tabular}

Keterangan:

So\% $=$ Persentase miskonsepsi total seluruh siswa pada tes awal

$\mathrm{S}_{\mathrm{t}} \%=$ Persentase miskonsepsi total seluruh siswa pada tes akhir

Sedangkan pada analisis perubahan konseptual, data dianalisis dengan menggunakan uji chi kuadrat hingga didapatkan hasil sebagaimana yang tercantum pada tabel 3 sebagai berikut:

Tabel 3. Hasil Analisis Perubahan Konseptual

\begin{tabular}{|c|c|c|c|c|c|c|c|c|}
\hline \multicolumn{2}{|c|}{ NO. Soal } & \multicolumn{4}{|c|}{ Frekuensi Miskonsepsi } & \multirow[t]{2}{*}{$x^{2}$ hitung } & \multicolumn{2}{|c|}{ Keterangan } \\
\hline Pre & Post & $n A$ & $\mathrm{Nb}$ & Nc & $\mathrm{Nd}$ & & $\begin{array}{c}\text { Perubahan } \\
(+)\end{array}$ & $\begin{array}{c}\text { Perubahan } \\
(-)\end{array}$ \\
\hline 1 & 1 & 1 & 6 & 3 & 12 & 10.08 & Signifikan & - \\
\hline 2 & 2 & 1 & 2 & 3 & 14 & 12.07 & Signifikan & - \\
\hline 3 & 3 & 0 & 0 & 1 & 19 & 19.95 & Signifikan & - \\
\hline 4 & 4 & 1 & 2 & 0 & 18 & 16.05 & Signifikan & - \\
\hline 5 & 5 & 0 & 0 & 2 & 14 & 14.93 & Signifikan & - \\
\hline 6 & 6 & 0 & 0 & 1 & 15 & 15.93 & Signifikan & - \\
\hline 7 & 7 & 0 & 3 & 1 & 15 & 15.93 & Signifikan & - \\
\hline 8 & 8 & 0 & 0 & 2 & 15 & 15.93 & Signifikan & - \\
\hline 9 & 9 & 0 & 0 & 5 & 15 & 15.93 & Signifikan & - \\
\hline 10 & 10 & 0 & 1 & 1 & 11 & 11.91 & Signifikan & - \\
\hline 11 & 11 & 0 & 1 & 0 & 20 & 20.95 & Signifikan & - \\
\hline 12 & 12 & 0 & 2 & 0 & 13 & 13.92 & Signifikan & - \\
\hline Total & & 3 & 17 & 17 & 181 & 173.16 & Signifikan & - \\
\hline
\end{tabular}

Pada soal esai ada dua aspek yang diamati yakni persentase kesalahan siswa sebelum dan setelah dilakukan perlakuan, serta signifikansi perbedaan kesalahan sebelum dan setelah diberikan perlakuan. Berdasarkan analisis yang telah dilakukan, didapatkan hasil persentase kesalahan sebelum dan setelah perlakuan sebagaimana yang tercantum pada tabel 4 sebagai berikut:

Tabel 4. Hasil Analisis Persentase Kesalahan Siswa

\begin{tabular}{ccccccr}
\hline $\begin{array}{c}\text { Jenis } \\
\text { Kesalahan }\end{array}$ & $\sum \mathrm{M}_{0}$ & \% $\mathrm{M}_{0}$ & $\sum \mathrm{M}_{\mathrm{t}}$ & \% $\mathrm{M}_{\mathrm{t}}$ & Selisih & $\%$ \\
\hline $\mathrm{A}$ & 478 & 80.47 & 64 & 10.77 & 414 & 86.61 \\
\hline $\mathrm{B}$ & 401 & 82.51 & 123 & 25.31 & 278 & 69.33 \\
\hline $\mathrm{C}$ & 614 & 84.22 & 127 & 17.42 & 487 & 79.32 \\
\hline
\end{tabular}




\begin{tabular}{ccccccc}
\hline $\begin{array}{c}\text { Jenis } \\
\text { Kesalahan }\end{array}$ & $\sum \mathrm{M}_{0}$ & \% Mo & $\sum \mathrm{M}_{\mathrm{t}}$ & \% $\mathrm{M}_{\mathrm{t}}$ & Selisih & $\%$ \\
\hline $\mathrm{D}$ & 125 & 77.16 & 6 & 3.70 & 119 & 95.20 \\
\hline $\mathrm{E}$ & 165 & 87.30 & 54 & 28.57 & 111 & 67.27 \\
\hline $\mathrm{F}$ & 104 & 77.04 & 40 & 29.63 & 64 & 61.54 \\
\hline
\end{tabular}
Keterangan:
$M_{0}=$ Kesalahan total seluruh siswa pada tes awal
$M_{t}=$ Kesalahan total seluruh siswa pada tes akhir
A $=$ kesalahan memahami penggunaan simbol
$\mathrm{B}=$ kesalahan penggunaan tanda-tanda operasional matematika
$C=$ kesalahan penggunaan satuan.
$\mathrm{D}=$ kesalahan mengkonversi satuan
$\mathrm{E} \quad=$ salah menggunakan rumus dikarenakan siswa belum bisa menganalisis soal-soal

Untuk menganalisis signifikansi perbedaan kesalahan siswa sebelum dan setelah diberikan perlakuan, data dianalisis dengan menggunakan uji statistik chi kuadrat. Berdasarkan hasil analisis, didapatkan hasil bahwa nilai Znitung $=56.99$, sedangkan nilai $Z_{\text {tabel }}=11.07$. Sehingga hasil analisis data tersebut dapat diinterpretasikan bahwa integrasi remediasi menggunakan model CORE berbantuan booklet dapat membantu siswa agar mendapatkan jumlah kesalahan yang berbeda secara signifikan setelah perlakuan. setelah itu, hasil analisis pada soal pilihan ganda dan esai diakumulasikan dan dikelompokkan menurut jenis kesulitan yang sesuai, hingga didaat hasil sebagi berikut sebagaimana yang tercantum ada tabel 5 sebagai berikut:

Tabel 5. Hasil Analisis Kesulitan Belajar Siswa

\begin{tabular}{lcccccc}
\hline $\begin{array}{c}\text { Jenis } \\
\text { Kesulitan }\end{array}$ & Pretest & $\%$ & Posttest & $\%$ & Selisih & $\%$ \\
\hline 1 & 149 & 91.98 & 26 & 16.05 & 123 & 82.55 \\
\hline 2 & 155 & 95.68 & 22 & 13.58 & 133 & 85.81 \\
\hline 3 & 1493 & 82.53 & 314 & 17.36 & 1179 & 78.97 \\
\hline 4 & 394 & 81.06 & 100 & 20.57 & 294 & 74.62 \\
\hline Total & 2214 & 82.83 & 462 & 17.28 & 1729 & 78.91 \\
\hline Keterangan: & & & & \\
1. $=$ kesulitan mengusai konsep \\
2. = kesulitan mengaitkan hubungan antar konsep \\
3. = kesulitan menguasai rumus \\
4. = kesulitan mengoperasikan rumus dalam menyelesaikan soal
\end{tabular}

Berdasarkan data pada tabel 5, dapat dilihat bahwa terjadi penurunan atau reduksi kesulitan belajar pada seluruh, maupun jumlah kesulitan total dari seluruh di tiap jenisnya. Sehingga jika membandingkan selisih kesalahan dengan jumlah kesalahan awal, didapatkan hasil variabel terikat dalam penelitian ini yaitu reduksi kesulitan belajar pada siswa setelah digunakan model CORE berbantuan booklet dengan nilai sebesar 82.55\% pada kesulitan menguasai konsep, 85.81\% pada kesulitan mengaitkan hubungan antar konsep, 78.97\% pada kesulitan menguasai rumus, dan $74.62 \%$ pada kesulitan mengoperasikan rumus. Jika dihitung secara keseluruhan, terjadi penurunan kesulitan belajar sebesar $78.91 \%$ dari kesulitan belajar awal seluruhnya setelah dilakukan integrasi remediasi menggunakan model CORE berbantuan booklet. 
Kemudian, untuk mengetahui tingkat efektifitas model CORE berbantuan booklet yang digunakan, hasil dianalisis menggunakan rumus sebagai berikut:

$$
\Delta S=\frac{S_{0}-\hat{S}_{a}}{S_{0}}
$$

(Wright dalam Miun, 2013).

Keterangan:

$\Delta S \quad=$ Harga proporsi penurunan jumlah siswa yang kesulitan belajar

$S_{0} \quad=$ Jumlah kesulitan belajar siswa saat pre-test

$S_{a} \quad=$ Jumlah kesulitan belajar siswa saat post-test

Setelah data dianalisis, didapatkan hasil efektifitas perlakuan integrasi remediasi menggunakan model CORE berbantuan booklet sebagaimana pada tabel 6 berikut:

Tabel 6. Tingkat Efektifitas Integrasi Remediasi

\begin{tabular}{ccccccc}
\hline Jenis Kesulitan & Pretest & $\%$ & Posttest & $\%$ & $\Delta S$ & Keterangan \\
\hline 1 & 149 & 91.98 & 26 & 16.05 & 0.826 & Tinggi \\
\hline 2 & 155 & 95.68 & 22 & 13.58 & 0.858 & Tinggi \\
\hline 3 & 1493 & 82.53 & 314 & 17.36 & 0.790 & Tinggi \\
\hline 4 & 394 & 81.06 & 100 & 20.57 & 0.746 & Tinggi \\
\hline Total & 2191 & 82.83 & 462 & 17.64 & 0.789 & Tinggi \\
\hline
\end{tabular}

\subsection{Pembahasan}

Ada empat jenis kesulitan belajar yang ingin diremediasi dalam penelitian ini, yaitu kesulitan menguasai konsep, kesulitan mengaitkan hubungan antar konsep, kesulitan menguasai rumus, dan kesulitan mengoperasikan rumus (Wenno, dkk, 2016). Untuk melihat tingkat kesulitan yang dialami siswa, ada dua faktor yang diamati, yaitu miskonsepsi dan kesalahan siswa dalam mengerjakan soal. Miskonsepsi diamati untuk mengetahui kesulitan belajar siswa dalam menguasai konsep, dan kesulitan mengaitkan hubungan antar konsep dengan menggunakan soal pilihan ganda two tier test sebagai instrument penelitiannya. Two tier test dengan alasan terbuka digunakan agar dapat diketahui juga alasan siswa dalam menjawab soal yang diberikan.

Untuk menganalisis kesulitan menguasai rumus dan kesulitan mengoperasikan rumus, faktor yang diamati yaitu kesalahan siswa dalam mengerjakan soal, yang dianalisis menggunakan soal esai sebagai instrumennya. Kesulitan belajar menguasai rumus meliputi kesalahan memahami penggunaan simbol, kesalahan penggunaan, serta kesalahan penggunaan satuan tanda-tanda operasional matematika, sedangkan kesulitan mengoperasikan rumus meliputi kesalahan mengkonversi satuan, kesalahan menggunakan rumus, serta kesalahan merubah rumus (Wenno, dkk, 2016). Oleh karena itu agar dapat mengidentifikasi empat kesulitan belajar siswa, peneliti harus menganalisis hasil remediasi miskonsepsi dan kesalahan siswa dalam mengerjakan soal.

Berdasarkan data pada tabel 2, miskonsepsi paling banyak yang dialami siswa sebelum kegiatan remediasi atau pada pretest terdapat pada nomor enam, bahwa siswa menganggap bandul memiliki kecepatan getar nol pada titik setimbang, karena bandul berada pada titik setimbang berarti bandul tidak bergerak sebesar 55.56\%. Padahal menurut konsepsi ilmuwan kecepatan bandul akan maksimal di posisi setimbang, dan akan nol di posisi tertinggi. Miskonsepsi dengan persentase tinggi lainnya terjadi pada nomor dua belas, yakni siswa menganggap bahwa gelombang dihasilkan oleh getaran partikel berpindah karena pada gelombang partikelnya selalu berpindah, dengan persentase sebesar $44.44 \%$, yang jika digabungkan dengan pendapat yang serupa pada nomor sebelas bahwa 
partikel pada gelombang berpindah, maka akan memiliki persentase sebesar 55.56\%. Padahal peristiwa gelombang disebabkan oleh getaran yang energinya merambat, namun pada peristiwa tersebut, partikel hanya bergetar di tempat, atau tidak berpindah.

Berdasarkan hasil analisis ditemukan pula siswa yang sudah memahami sebagian konsep dengan benar namun kurang tepat. Contohnya seperti pada soal nomor dua, siswa menjawab bahwa simpangan memiliki jarak lebih kecil dan amplitude memiliki jarak lebih besar. Ini menunjukkan bahwa siswa sudah memahami bahwa jarak simpangan lebih kecil daripada amplitude, namun masih terdapat kekeliruan, yakni amplitude tidak hanya memiliki jarak lebih besar, namun harus memiliki jarak terbesar dari titik seimbang, sehingga jika jaraknya belum mencapai titik maksimum, maka belum dapat dikatakan sebagai amplitudo. Alasan yang kurang tepat juga terjadi pada nomor tujuh, yakni siswa menganggap bahwa pada peristiwa gelombang energinya merambat, sehingga partikelnya juga pasti ikut merambat. Ini menunjukkan bahwa siswa sudah paham bahwa pada gelombang terjadi rambatan energy, namun siswa belum memahami bahwa walaupun energi pada gelombang merambat, namun partikel gelombang tidak berpindah. Sedangkan pada posttest persentase miskonsepsi yang dialami siswa tidak ada yang melebihi 20\% pada tiap nomornya.

Data jawaban siswa pada soal pilihan ganda kemudian dianalisis dengan menggunakan uji McNemar sebab nilai E yang didapat lebih besar daripada 5. Uji dilakukan dengan $\mathrm{dk}=1$ dan $\alpha=5 \%$ pada seluruh nomor tes, untuk mengetahui apakah terjadi perubahan konseptual pada siswa atau tidak. Berdasarkan hasil analisis, didapatkan hasil bahwa seluruh nomor memiliki nilai yang lebih besar daripada $X^{2}$ tabel yaitu 3.481. Ini menunjukkan bahwa setelah diterapkan integrasi remediasi menggunakan model CORE berbantuan booklet dapat mengubah konsepsi siswa secara signifikan pada seluruh nomor tes konsep yang digunakan, yakni dari mengalami miskonsepsi, menjadi tidak miskonsepsi. Ini menunjukkan bahwa model CORE dapat membantu siswa dalam penguasaan konsep (Shoimin, 2017), begitu juga dengan booklet sebagai instrument pendukung yang dapat digunakan untuk mengatasi miskonsepsi (Christoporus, 2010). Terbuktinya terjadi perubahan konseptual pada siswa juga menunjukkan bahwa integrasi remediasi model CORE berbantuan booklet dapat membantu mengatasi kesulitan belajar siswa dalam memahami konsep dan mengaitkan hubungan antar konsep yang tercakup dalam soal konsep pilihan ganda berbentuk two-tier test yang digunakan.

Untuk menganalisis kesulitan belajar siswa dalam menguasai rumus dan mengoperasikan rumus, dilakukan analisis jawaban siswa pada soal esai, dengan mengamati persentase kesalahan siswa dalam menyelesaikan soal pada pretest dan posttest, serta signifikansi perbedaan kesalahan keduanya. Berdasarkan data pada tabel 4 dapat dilihat bahwa pada pretest tingkat kesalahan yang dialami siswa berada di atas 60\%, artinya lebih dari setengah dari seluruh sampel masih mengalami kesalahan dalam menyelesaikan soal, baik simbol, operasional matematika, satuan, konversi satuan, penggunaan rumus, hingga merubah rumus.

Pada kesalahan simbol, persentase kesalahan pada pretetest memiliki nilai sebesar $80.47 \%$, ini menunjukkan bahwa sebagian besar siswa masih belum dapat mengidentifikasi seluruh simbol fisika dari besaran-besaran tentang getaran dan gelombang, sedangkan pada posttest, persentase kesalahan turun menjadi 10.77\%. Dalam jenis kesalahan ini, kebanyakan ditemukan jawaban siswa yang tidak mencantumkan data sesuai simbol fisika yang tepat, siswa hanya menulis data dengan menggunakan kalimat utuh. Kesalahan simbol menurut hasil penelitian Djarod (2015) termasuk dalam kesalahan terjemahan, dan biasanya disebabkan siswa kurang memperhatikan guru ketika menjelaskan, lupa, belum terbiasa, kurang cermat dalam membaca soal ataupun kurang mengerti.

Pada kesalahan satuan, ditemukan hasil bahwa siswa seringkali tidak menuliskan satuan, ataupun menuliskan satuan yang salah. Saat pretest, persentase kesalahan siswa memiliki nilai sebesar $84.22 \%$, dan turun menjadi $17.42 \%$ pada saat posttest. Menurut Hastuti, dkk (2012), kesalahan satuan dapat menjadi penyebab siswa juga mengalami kesalahan perhitungan matematis, oleh karena itu, pemahaman penggunaan satuan penting untuk dikuasai dalam ilmu fisika. Menurut Hastuti, dkk (2012) salah satu penyebab siswa salah dalam menuliskan satuan, yakni dikarenakan siswa terbiasa hanya menghafal tanpa memahami. 
Pada kesalahan operasional matematika, persentase kesalahan juga turun dari $82.51 \%$ pada pretest menjadi 25.31\% saat posttest. Hasil pengamatan menunjukkan bahwa bentuk kesalahan yang dilakukan siswa berupa siswa tidak teliti dalam operasi hitung, terutama pembagian dan perkalian bilangan desimal. Beberapa siswa telah menggunakan cara yang benar, namun salah di perhitungannya. Menurut Sari, dkk (2013) kesalahan perhitungan matematis dapat terjadi karena siswa kurang terampil dan kurang teliti dalam operasi hitung.

Pada kesalahan konsversi satuan, siswa kesulitan mengkonversi satuan yang masih jarang mereka temui, seperti Hertz, misalnya dari kHz menjadi $\mathrm{Hz}$, padahal prinsip yang digunakan sama dengan mengkonversi kilogram menjadi gram yang telah siswa pelajari di sekolah dasar. Siswa juga mengalami kesulitan dalam mengkonversi satuan yang memiliki lebih dari satu besaran, misalnya mengkonversi satuan kecepatan dari km/jam menjadi m/s. Kesalahan mengkonversi satuan menjadi Satuan Internasional (SI) menurut Juwariyah (2018) termasuk sebagai salah satu penyebab siswa dapat mengalami kesalahan dalam menterjemahkan soal yang ditanya, sehingga siswa tidak dapat menjawab soal dengan tepat. Persentase kesalahan ini menurun dari $77.16 \%$ menjadi $3.70 \%$ pada posttest.

Berdasarkan hasil pengamatan, ditemukan bentuk kesalahan siswa dalam menggunakan rumus yang paling umum berupa siswa tidak menuliskan rumus dibutuhkan, serta salah dalam memilih rumus yang tepat untuk menjawab soal yang ditanyakan. Menurut Juwariyah (2018), kesalahan dalam menentukan rumus menjadi salah satu penyebab siswa mengalami kesalahan menentukan strategi pemecahan soal, sebab ketika siswa salah dalam menentukan rumus, maka siswa juga salah dalam menentukan urutan langkah penyelesaian soal. Pada pretest, kebanyakan siswa yang tidak mencantumkan rumus juga tidak melanjutkan pengerjaan soal, sehingga jawabannya kosong, namun ada pula siswa yang menjawab dengan langsung mengalikan atau membagi nilai besaran yang diketahui tanpa langkah yang jelas. Untuk siswa yang salah menentukan rumus, juga ditemukan bahwa kebanyakan siswa tidak melanjutkan pengerjaan soal, sebab besaran yang diperlukan dalam rumus yang dicantumkan tidak diketahui nilainya. Sedangkan pada posttest ditemukan beberapa siswa yang menjawab soal dengan benar, namun tidak mencantumkan rumus yang diperlukan, sehingga langsung mengoperasikan soal secara matematis. Menurut Efrilia (2016), kesalahan rumus dapat terjadi karena siswa hanya belajar pada saat akan ada ulangan dan tidak mengulang kembali pelajaran yang dipelajari di sekolah. Persentase kesalahan ini turun dari $87.30 \%$ pada pretest menjadi 28.57\% pada posttest.

Pada kesalahan siswa dalam merubah rumus sesuai variabel yang ditanyakan dalam soal juga terjadi penurunan persentase kesalahan, yakni dari $77.04 \%$ pada pretest menjadi $29.63 \%$ pada posttest. Bentuk kesalahan yang ditemukan yakni kebanyakan siswa hanya mengosongkan jawaban, ataupun langsung menulis rumus hasil konversi tanpa langkah pengkonversian yang jelas. Pada pretest, kebanyakan siswa yang tidak dapat mengkonversi rumus dengan tepat tidak melanjutkan pengerjaan soal, sehingga hanya mengosongkan jawaban. Namun pada posttest ada beberapa siswa yang langsung menuliskan rumus jadi tanpa proses konversi yang jelas. Ini menunjukkan siswa belum dapat menguasai pengkonversian rumus dengan benar, dan hanya menghapal rumus akhir yang dibutuhkan.

Untuk mengetahui signifikansi perbedaan kesalahan pretest dan posttest, data jawaban siswa dianalisis dengan menggunakan uji Chi Kuadrat. Dari hasil perhitungan uji chi kuadrat (chi square) diperoleh nilai $\chi_{5 \%(5)}^{2}>\chi_{\text {tabel }}^{2}$ yaitu $56.99>11,070$ yang dapat diputuskan bahwa terdapat perbedaan yang signifikan pada jumlah kesalahan siswa dalam menyelesaikan soal uraian getaran dan gelombang antara sebelum dan sesudah integrasi remediasi menggunakan model CORE berbantuan booklet. Sehingga dapat disimpulkan pula bahwa integrasi remediasi menggunakan model CORE berbantuan booklet dapat membantu siswa dalam mengatasi kesalahan menyelesaikan soal secara signifikan.

Untuk menjawab tujuan penelitian umum, dilakukan uji efektifitas menggunakan harga proporsi penurunan yang kemudian dibandingkan dengan skala ruas tiga jari. Berdasarkan analisis tersebut didapat hasil proporsi penurunan secara berurutan yaitu: 0.826 untuk kesulitan menguasai konsep, 0.858 untuk kesulitan mengaitkan hubungan antar konsep, 0.790 untuk kesulitan menguasai rumus dan 0.746 untuk kesulitan mengoperasikan rumus, serta 0.7898 untuk total semua jenis kesulitan belajar. Semua hasil yang didapatkan menunjukkan kalau perlakuan 
yang telah dilakukan memiliki efektifitas tinggi. Oleh karena itu dapat disimpulkan bahwa integrasi remediasi menggunakan model CORE efektif dapat mereduksi kesulitan belajar siswa tentang getaran dan gelombang di SMP Negeri 2 Pontianak.

\section{Kesimpulan}

Berdasarkan hasil penelitian, secara umum dapat disimpulkan bahwa integrasi remediasi menggunakan model CORE berbantuan booklet efektif untuk mereduksi kesulitan belajar siswa tentang getaran dan gelombang di SMP Negeri 2 Pontianak.

\section{Referensi}

Asrori, M dan Mohammad Ali. (2014). Metodelogi dan Aplikasi Riset Pendidikan. Jakarta: PT Bumi Aksara.

Calfee, et al. (2004). Making Thinking Visible. National Science Education Standars. USA: University of California.

Christophorus dkk. (2017). Penyediaan Booklet untuk Meremediasi Miskonsepsi Siswa Kelas VIII Pada Materi Getaran dan Gelombang. Skripsi: Universitas Tanjungpura.

Dewi, H. R, dkk. (2016). Analisis kesulitan belajar IPA materi gerak pada siswa kelas VII MTs Sunan Ampel. Makalah Pendamping Seminar Nasional Pendidikan Fisika II 2016 pada 28 Mei 2016, Madiun.

Djarod, F. A., dkk. (2015). Analisis Kesalahan dalam Menyelesaikan Soal Materi Pokok Termodinamika pada Siswa Kelas XI SMA Al Islam 1 Surakarta Tahun Ajaran 2013/2014. Jurnal Prosiding Seminar Nasional Fisika dan Pendidikan Fisika (SNFPF) Ke-6. 6 (1), 306-312.

Efrilia, D. (2016). Analisis Kesalahan Siswa dalam Menyelesaikan Soal Fisika Pada Materi Gerak Lurus di Kelas VII SMP Negeri Purwodadi Tahun Ajaran 2015/2016. Jurnal Pendidikan Fisika STKIP - PGRI Lubuklinggau. 1 (1), $1-15$.

Eikici, E. (2016). "Why Do I Slog Through the Physics?" Understanding HighSchool Students' Difficulties in Learning Physics. Journal of Education and Practice. 7 (7).

Hastuti, dkk. (2012). Analisis Kesalahan dalam Menyelesaikan Soal Materi Pokok Kalor pada SIswa Kelas X SMA. Jurnal Materi dan Pembelajaran Fisika. Vol 2, 1-11.

Juwariyah, Siti, dkk. (2018). Analisis Jenis Kesalahan Siswa Dalam Menyelesaikan Soal Fisika Materi Listrik Statis Di Man 6 Jombang. Jurnal Pembelajaran Fisika. 7 (3), 255-262.

Miun, Yesinta M. (2013). Integrasi metode scramble Dalam Pembelajaran Ulang untuk Meremediasi Kesulitan Belajar Siswa Kelas VII SMP Immanuel II Sungai Raya Pada Materi Hukum Newton. Skripsi: FKIP UNTAN.

Nurussianah. (2016). Efektivitas Penggunaan Booklet Untuk Meremediasi Kesalahan Siswa pada Materi Pemuaian Zat Di Kelas VIII SMP Negeri 1 Tangaran Kabupaten Sambas. Jurnal Edukasi Matematika dan Sains, 4 (2).

Sari, D. M., (2013). Analisis Kesalahan dalam Menyelesaikan Soal Materi Termodinamika pada Siswa SMA. Jurnal Materi dan Pembelajaran Fisika (JMPF), 3(1), 5-8.

Satriani, Gusti Ayu Nyoman Dewi, dkk. (2015). Pengaruh Penerapan Model CORE terhadap kemampuan pemecahan masalah matematika dengan kovariabel penalaran sistematis pada siswa kelas III Gugus Raden Ajeng Kartini Kecamatan Denpasar Barat. e-Journal Program Pascasarjana Universitas Pendidikan Ganesha Program Studi Penelitian dan Evaluasi Pendidikan. 5 (1).

Shoimin, Aris. (2017). 68 Model Pembelajaran Inovatif dalam Pembelajaran 2013. Yogyakarta: Ar-Ruzz Media.

Silitonga, H.T.M, dkk. (2019). The Implementation of Integrated Remediation with Conceptual Interactive Learning on Momentum and Impulse in Senior High School. IOP Conf. Series: Journal of Physics Series 1171.

Sutrisno, L. Kresnadi, dan Kartono. (2007). Pengembangan Pembelajaran IPA SD. Jakarta: PJJ S1 PGSD. 
Wenno, Izzak, dkk. (2016). Analisis Kesulitan Belajar dan Pencapaian Hasil Belajar Siswa Melalui Strategi Pembelajaran Inkuiri. Cakrawala Pendidikan. TH. XXXV No. 3.

Yuniarti, 69 Santi. (2013). Pengaruh Model Core Berbasis Konstektual Terhadap Kemampuan Pemahaman Matematik Siswa. Skripsi: STKIP Siliwangi Bandung.

JIPPF, Vol. 1, Edisi 1, Halaman: 17- 28 